\title{
THE POWER OF MUSIC: ISSUES OF AGENCY AND
}

SOCIAL PRACTICE

Door prof. Norman Long

Rede, uitgesproken op 13 december 2001 ter gelegenheid van het afscheid als hoogleraar in de Rurale Ontwikkelingssociologie, departement Maatschappijwetenschappen, leerstoelgroep Rurale Ontwikkelingssociologie aan Wageningen Universiteit. 


\section{Rector Magnificus, Ladies and Gentiemen,}

On an occasion such as this, one is usually expected to look back over one's academic career and reflect upon some of the central issues one has grappled with over the years. I have decided, instead, to explore how a few of the insights arising from my work might fruitfully be applied to another field - and one which interests me very much, namely music.

The understanding of music - its creation, its performance and its reception - has been a longstanding interest of mine, though this lecture represents a first attempt to systematise some of my thoughts about it. In my youth, writing, performing and listening to music was my absorbing passion. It even seemed likely that I might one day make it my vocation. But, for various reasons, this was not to be. Instead I became a social anthropologist working on the sociology of development. This lecture affords me the opportunity and motivation to talk briefly about my rejuvenated interest in the practice and interpretation of music. More specifically, I wish to show how a sociological perspective of the kind I have developed in my research and writings on development and social change can open up new lines of inquiry in regard to music. In addition, I believe that careful ethnographic studies of musical practice - at the points of composition, performance and reception - can provide us with valuable data and insights on processes of cultural and organisational change. Musical experience and the making of music involve the capacity to absorb new and rework old elements but not by assuming simply that we are witnessing the global melting pot of musical styles and tastes called 'world music' or 'fusion'. 


\section{The significance of music and musical practice}

Throughout history, music has of course been a powerful symbol of cultural identity and aspirations and it continues to be so in our present era of globalised production and consumption. Like painting, sculpture and the performing arts, music - of whatever kind, classical, folk, pop or jazz - evokes a wealth of associations of an emotional and social kind. Anthems, for example, are a symbol of national pride and cohesion, and often generate strong emotions and identifications, especially at times of celebration or crisis. This was poignantly brought across to me on the morning following the tragic events of the $11^{\text {th }}$ of September, when, as a mark of solidarity, the military band attending the Changing of the Guards at Buckingham Palace struck up the American anthem instead of the expected 'God Save the Queen', dramatically transforming the mood of the event for the usual gathering of tourists outside the Palace gates. ${ }^{2}$

The symbolic and political significance of music in this example is obvious, and it would be easy to illustrate how other genres of music have strong associations with other types of social event. Indeed much musicology has been devoted to exploring this direct link between musical styles and their social and cultural content. ${ }^{3}$ Yet, while the idea of music being a 'force' in social life may seem unproblematic, adopting this approach to its composition and performance has major limitations, since it does not account for how in the first place the genie of music got into the bottle, nor how it is "decanted into society" (DeNora 2000: $3)$. That is, it provides no appreciation of the ways in 
which composers and musicians engage with each other, and with other actors that make up their networks of audiences, sponsors, competitors, colleagues, friends and partners, in the production, performance and consumption of music.

Pursuing a similar methodological argument, Michael Bakan - an ethnomusicologist and professional percussionist who set out to probe the intricacies of the gamelan percussion orchestras of Bali - explains how he had to apprentice himself to an expert gamelan musician in order to achieve an understanding of the dynamics of composition and performance of this music. Only then could he establish a link between musical practice and the embodiment and transmission of the powerful cultural symbols and political identities that belong to this musical tradition. Adopting this strategy enabled him to delve into the internal negotiations and struggles taking place within and between different gamelan groups. This revealed how personal reputations, skilful musicianship and political clout were intimately intertwined (Bakan 1999).

These opening remarks point to certain parallels with the kind of theoretical approach that I have championed in the sociology of development over the last two decades.

\section{A brief sociological portralt: issues of agency and knowledge}

Much of my working life has been directed towards 
understanding processes of social change in the countryside. This has entailed detailed ethnographic research on rural transformations in different settings in Africa and Latin America and, like the gamelon player, this has allowed me to experience at first hand the place that music enjoys in everyday life.

Theoretically much of my research has addressed itself to the issue of 'human agency'. ${ }^{4}$ This concept attempts to embrace - in a single phrase - the complexity associated with how certain acts of doing and reflecting impact upon or shape - though not always intentionally - the actions and understandings of others. While agency is normally said to pertain to individuals and groupings of people who can process their experiences and come to joint decisions, agency may also be attributed, to a degree, to objects and ideas, including music (cf. Gell 1998: 20 on the agency of art objects). Indeed musical production and performance have powerful agency when they significantly impact on people's understandings, feelings and actions.

A further angle on agency is its relationship to the idea of creativity and social innovation. In general parlance, creativity is said to be a product of innovative 'minds' and special 'talents'; and therefore linked to the cognitive agility and inventiveness of extraordinary individuals, especially the masterminds of science and the arts. 5 Undoubtedly such rare individual capacities can bring major change to the worlds in which we live: note the impact of scientists such as Darwin and Einstein, or of composers such as Mozart 
and Beethoven. Sociology too can lay claim to its own geniuses, like perhaps Karl Marx and Max Weber. But we should not forget the equally (or perhaps more) important point that the 'invention' of new knowledge and understandings - in whatever field - is always underpinned by various social, cultural and institutional components. Hence it has been argued (DeNora 1997) that Beethoven's rise to stardom as an acknowledged genius or giant among his peers cannot properly be understood without providing a picture of the political and social structures of Vienna at the turn of the $19^{\text {th }}$ century, nor without an analysis of the social connections he developed with influential aristocrats and with Haydn and other well-placed musicians. ${ }^{6}$ We must also remember that creativity is not the monopoly of 'experts' and 'intellectuals' but is also manifest in the creative and strategic abilities of ordinary 'lay' persons and amateurs. This is evidently the case across many fields of activity and music is no exception.

Another issue I have taken up in my work is that of how knowledge is constructed and reworked through everyday social practice 7 . Such an approach does not see knowledge as simply the product of some readymade framework or grid for understanding or system of beliefs and values. Knowledge and what might be called 'new creativities' result from and are constantly shaped by the experiences and encounters that emerge at the points of intersection between people's lifeworlds ${ }^{8}$ and this is no less the case with music. 


\section{Agency and music}

Let me turn now to consider more specifically how creativity, knowledge and agency relate to music. Listening to music engenders a mixture of feelings, thoughts and behavioural responses. One might tap one's foot, mime the beat, sway or dance, cry or laugh. Such reactions can be highly personal, shared with others, or they can be collectively enacted. In this manner, music can trigger off for the listener a whole series of symbolic associations with real or imagined places, events, and social experiences that may be distantly located in time and space. It can also evoke strong value commitments and a sense of solidarity with other persons that may motivate individuals and groups to join together in the pursuit of common goals or in opposition to the interests and desires of others. Note, for instance, the way in which football fans burst into a song before a match as well as at critical moments of the game when they endeavour to drown out the voices of the opposition and drive their team onwards to victory. This has produced some spectacular performances of favourites such as 'You'll Never Walk Alone', which, I believe, was originally adopted by supporters of Liverpool United Football Club.

In other public contexts, music forms part of a multidimensional aesthetic performance which draws upon simultaneous sound, movement, visual imagery and language to define and communicate a complex set of symbolic and practical meanings. We can illustrate this briefly by reference to the many village and regional fiestas performed throughout the highlands of Peru on specific Saint's days. An especially interesting 
part of these celebrations concerns the dance dramas (or danzas) performed by masked and costumed dance troupes, who are accompanied by musical ensembles (orquestras tipicas) playing a combination of traditional Andean and Spanish instruments. 9 These danzas portray and scoff at the ethnic divide that exists between indios (indians) and mestizos (persons of mixed descent), and in so doing ridicule both social categories. They also expose the fragility of mestizo authority and control in the face of the subtle strategising and subversiveness of so-called 'subordinated' indios. The beauty of these danzas is that narratives and meanings are communicated simultaneously in a choreography of music and dance. The dance routines also include attempts by clowns or buffoons wearing animal masks to control the audience by playfully whipping the legs of targeted individuals. This, along with the lively dancing, encourages interaction between the performers and the heterogeneous public. But, of course, without the music to project the shifting moods, meanings and expressive body movements of the dancers and the audience, the whole performance would fall flat.

This underscores the uniqueness of musical idioms and performance. Like dance, music is special since its effects generate not so much language-based understandings or meanings but instead a complex of emotional and feeling-based states of mind and body.10 Hence music and what it communicates cannot easily be submitted to semiotic types of analysis. That is, it cannot be reduced to constructed narratives or 'story lines' and textual messages, even when words are sung to it or evocative titles provided by the composer or 
when textual interpretations are added to the concert programme or $\mathrm{CD}$. It involves, that is, complex sensitivities that arise from the simultaneous engagement of sound, movement, emotions, thoughts, social relations and context - but seldom much language-based interpretative material. This is especially the case with instrumental art music of the late classical and early romantic periods, built as they are on certain strict conventions of form and harmony. And, although philosophically and musically quite different, the abstract compositions of twentieth century 'minimalist' composers exhibit similar characteristics. "In fact neither provide much in the way of clues as to how to connect the sound bites of particular music to the 'human condition', so graphically portrayed in grand opera or in the dance dramas of Peru. Thus it remains with the performers, listeners and music critics to develop their own interpretative and strategic responses grounded in their own experiences, memories, feelings, moods, knowledge and values. But if music and musical practices are to reach out and affect people's personal and social worlds more widely or collectively, then we need to know more about how this happens. This raises the issue of the emergence and significance of musically-based social movements and 'schools of thought', as well as, of course, how listeners and performers are 'boxed in' by the advertising and staging of musical events. It also suggests the need to look more closely at the role played by organisations such as sound and video recording companies and their sales departments in the management of the meanings and experience of the music and music groups they market. Another area of growing concern relates to those companies specialising in the provision of piped 
music in public areas such as shopping malls and airports.

\section{The dynamics of musical performance: the Guarneri Quartet speaks out}

I want now to examine issues relating more specific to the live performance of music. But first, one word of caution. When I speak of 'performance' I do not imply some kind of musical template designed to judge how 'good' the performance is. I leave this to music critics and examiners to worry about. Nor do I assume, as some people might, that in playing music one is principally interested in attaining a uniformity of style that pleases the consumer/listener or conforms to the model of 'good music' as defined by some specific school of thought. Musical performances are varied and unpredictable and performers are constantly involved in journeys of discovery that only later, after they are over, can they adequately define.

An interesting observation on why musical practice should lack ready-made plans for achieving "a constant unanimity of style and approach" is contained in David Blum's (1986) conversations with members of the Guarneri String Quarter. When asked how they had "forged a unity of conception in [their] quartet playing", the players replied that they just didn't think they had ever achieved it. The first violinist explained that actually over the past twenty years or so they may "have moved further apart, because", as he put it, "each of our musical personalities has continued to evolve in its own way. It's important that each of us go 
on his own musical voyage through life, whatever it may be." The viola player reiterated this, saying "I am happily surprised on occasion to find myself totally wrong about what I think a player will do, or how he'll react in a particular passage..... There's a wonderful passage towards the end of the first movement of the Debussy Quartet when the second violin and the viola have to act as one player....... Now in this passage John [the second violin] and I play a little unspoken game. He knows that he's throwing me curves, and that I sometimes have to stand on my head to catch them. But I've never once said, 'John, let's rehearse that. Tell me what you want to do, and I'll try my damnedest to do it with you'. I'd rather not play quartets at all than nail everything down in advance".

In effect, what they are each saying is that quartet playing, particularly at this level, consists of a strong counterpoint of four individual voices, each seeking to shape the direction in which the music moves. This dynamic interplay, made explicit by the musicians themselves, clearly parallels the ways in which other non-musical - encounters are constructed, and their social relationships constantly made and remade. Ongoing tussles and gymnastics over musical interpretation and performance lead to emergent and often unforeseeable outcomes, just as do social practices in other arenas of contestation, even those characterised by careful planning and anticipation. It is argued therefore that an understanding of the framing and organisational dynamics of social life is best achieved through a detailed analysis of the processes by which social practices and meanings (in this case musical performances) are constituted, re-invented or trans- 
formed. In so doing we must give some priority to identifying the ways in which certain continuities are retained, while on the other hand not forgetting the point made by the Guarneri Quarter, namely that every live performance brings to the fore new and unpredictable elements - not only for the audience but also for the players.

In the rest of the lecture I present two contrasting musical scenarios to illustrate several of the points I have already made. I focus especially on issues of musical performance and composition, leaving over for another time the question of how audiences receive and process music at the many different sites in which music is heard. That will give me plenty to do in my retirement.

\section{Musical and ritual practices in the Mantaro region of highland Peru}

The first musical scenario takes us back to the brief reference I made to changing musical and cultural practices in the central highlands of Peru, where I have worked on and off for many years. ${ }^{12}$ Here I focus primarily on the dynamics of performance.

Festive and ritual occasions in Peru are almost always embroidered with musical performances. Broadly speaking these fall into two different, though related, genres. The first concerns ritual events enacted within the private space of the family domain that mark out critical stages or events of the agricultural season and life cycle. The second relates to public events (religi- 
ous or secular) that reaffirm the significance of 'community' solidarities and divisions linked to a sense of belonging to particular localities (such as the village, town, region or migrant neighbourhood) or status hierarchies based on ethnic, gender or life style differences.

Towards the end of July each year, livestock owners, together with kin, friends and workers, celebrate the survival and fecundity of their herds with an ear tagging (berranza) ceremony that takes place in the owner's backyard or cattle kraal. The ritual ensures the continuing prosperity and fertility of the herd and is the time when offerings to mountain spirits (wamani) are made to guarantee their continued welfare. The tagging is also a way of marking off the animals from those of other livestock owners. While commonplace throughout the highlands, the forms and meanings it conveys in the Mantaro valley vary somewhat from those of other highland regions. In particular, making offerings to mountain spirits (wamani) does not feature to the same degree as we find in accounts of the ceremony from the southern Andes. ${ }^{13}$

The event begins ${ }^{14}$ with the women of the household stringing together necklaces of fruit and sometimes bread to place around the necks of the animals during the ceremony. The musicians practice their instruments - the violin and cornet made from a ram's horn. And the woman who will play the role of the herdswoman the pastora, prepares the tinya or small drum that will accompany the songs she will sing. Throughout these preparations and the performance that follows, the participants drink a crude sugarcane alcohol and chew coca leaves. 
The songs and exchanges that take place during the tagging ceremony tell of the hardships involved in caring for the animals throughout the year in the high mountains, until they are brought down to the lower pastures, and back to their owner or patron for inspection. The herdswoman sings of how she has now come to claim her reward for the all the sufferings she has endured:

With my cow I am coming, my patron ['Father' owner 15]

Dancing I am coming, with choice rum and your coca....

Bring out your granary, for I am hungry...

She sings of the animals and their new offspring, of the loneliness and long distances travelled in the mountains and of the obligations towards her that the patron must fulfil. She complains that 'she is in servitude' and seeks recompense (recompensa). Through the songs, she attempts to negotiate what she considers her due for caring for the animals. From time to time, she also relates to the others that are present for instance, encouraging other herdswomen there to join in and support her protest, and drawing attention to the several migrants who have returned for the ceremony from the mines where they work. For his part, the patron expresses doubts about the pastora's honesty, retorting that she is cheating him about the animals that have perished during the year, as well as the number of new offspring. This bantering through song remains a central feature of the exchanges that take place between the two of them. 
Then, during the piercing of the animals' ears, the herdswoman sings a song for the animals as she places the fruit and flower garlands around their necks. After this, with the help of the men, each of the animals is, in turn, brought to the ground so that a coloured ribbon can be sewn to each ear. The animal is then forcefeed with chicha (a maize beer), and the blood from the ears mixed with the best quality coca leaves and then buried in the earth as an offering to ensure the continuing fertility of the animals. When all is over, the herdswoman sings her farewells, with the other women joining in in solidarity with her. Once again, they sing about the patron and how he is making himself rich selling the animals and buying himself finery, while they remain poor. The patron sings an answer: how come so many cows get lost? How many accidentally died?

Later, the songs recast this theme of the herdswoman vis-à-vis the patron in terms of more general male/female relationships, and the struggles that occur between husband and wife over priorities of livelihood and control of family affairs. At this juncture, the musical instruments dialogue with each other in oppositional melodic and rhythmic patterns, with the violin providing more sombre interludes between the more frenetic passages.

Towards the end of the ceremony, when the company is merry from drinking and dancing, there is much teasing and joking between the sexes with a lot of sexual innuendo. Finally the men lasso the herdswoman and pull her to the ground. One of the male participants, at this point, shouts for joy, singing: 'when you tumble with a female to the ground there is more 
harvest - it is beautiful'. Here, of course, he refers simultaneously to the sexual excitement and fecundity of women as well as to the reproduction of the herd. Yet, despite this playful element introduced by the intervention of men towards the end of the drama, it is the herdswoman who leads the musical ensemble, the animals and the other participants throughout the performance. Her controlling role, in effect, reflects her position in caring for the livestock, a key resource in the management of the household and farm economy. Thus, although a herdswoman is in some ways clearly subordinate to the wishes of the patron and dependent on his good favours, on the other hand, her detailed knowledge and management of the animals and their grazing areas gives her strategic advantage in furthering her own interests and not merely defending them. This highlights the complex dynamics involved in, what Villarreal (1994: 263) has elsewhere described as, "the wielding of power... through the exercise of yielding to it."

The social encounters depicted in this tagging ritual are clearly staged but improvisation is an expected part of the performance. But care is taken in berating the patron and others so as not to cause real hurt or offence. That is, the participants are aware that this is a ritual and musical performance that allows for a release of tensions, but equally they know that such stylised presentations - tinged as they are with a degree of aggressiveness - can easily spill over into a realpolitik involving negotiations over labour and remuneration once the ritual jesting is over.

The ceremony represents a unity of sound and action. 
The music played at the event is unique to this context and does not form part of any other social or ritual context. It is said that the ram's horn cornet was specifically designed for use at this ceremony and is only rarely played on other occasions. The horns are cleaned and stored away at the end of the ceremony ready for the next year. The style of music not only has a functional role in the ritual - stimulating dancing and generating a certain emotional intensity - but the songs themselves act as a vehicle for expressing certain demands, opinions and sentiments that would not normally be possible to verbalise directly in day-today life. To do so would offend persons of status and lay oneself open to general social disapproval.

\section{Ringing the musical changes}

Despite the escalating pressures of 'modernity', the music and ceremonial tagging of animals still persists as a family-focused activity in the Mantaro region. But more visibly impressive is the huge expansion of village and small town festivities, especially those associated with the celebration of Christian Saints' days and the events of the life of Christ. These fiestas begin with a mass, followed by the processing of the Saint's image or figure of Christ through the streets, and then continue over a number of days with a range of social events. The latter usually include dance displays organised by religious or social associations, each accompanied by a brass band or small orchestral ensemble. They may also consist of bullfights, horse riding displays and other competitive events, and disco dancing. The kinds of fiestas characteristic of the Mantaro Valley are commonly described as mestizo in culture 
and social organisation. That is, they are permeated by the values, life styles and hybrid forms of music and dance practised by Spanish-speaking persons of supposed mixed Spanish and Indian descent.

Many of these religious fiestas have been revitalised and transformed in tandem with the increased integration of the area into wider national and now more global networks. During the early years of the twentieth century, the increasing movement of men, women and families in search of work and education to the mining towns and then later to the metropolitan centre of Lima-Callao increased the flow of cash, manufactured goods, and new-found skills from urban and industrial locations to the villages and towns of the highlands. This flow of people and cash, together with the opening up of new fields of information and contacts, led to massive investment in fiestas, as well as in local development projects such as the building of schools, town halls, sports stadia, bull rings and so forth in the villages and towns of the region.

These developments led not only to an expansion in the scale and cultural repertoires of fiesta events but also to the professionalisation of musicians and to the formation of larger orchestral ensembles and bands. One interesting example of this move to professionalism is that of the village of Acolla which is now wellestablished as a centre for the training of musicians. This process was set off almost by chance when a handful of young men from Acolla were recruited for military service and had the good fortune to spend most of their time learning various wind instruments 
and playing in military brass bands. Later, on their return to Acolla, they set about training a whole new generation of musicians, who subsequently founded several bands and orchestras that now occupy a prominent place in music-making throughout the central highlands, and, in some cases, even at national level. This new generation of musicians learnt to play newly introduced instruments such as saxophones and clarinets, as well as high precision brass instruments such as trumpets, trombones and tubas. These instruments have now taken their place alongside already existing Andean instruments such as the harp, recorder-type flutes (quenas), mandolins, guitars, harps, violins and small drums.

These developments have stimulated the further elaboration of the musical dance dramas I mentioned earlier, which have became a central feature of both religious celebrations and secular folklore festivals and dance competitions throughout the area. ${ }^{16}$ No other festive event, except perhaps the mass and the saint's day procession, can surpass these dance dramas for their capacity to express popular feelings of mestizo identity and history. Each dance drama is characterised by a well structured choreography, a theatrical quality, and masked dancers, bedecked in brightly coloured, embroidered costumes that evoke the mythical-historical origins of the place and events. The musical numbers played for these dramas have their own specific rhythmic and melodic idioms, but are constantly being reworked through the improvisation of new passages and harmonic combinations as musicians of the bands and orchestras travel around the region performing at different festive locations. It 
is not unusual before the commencement of major fiestas and dance competitions to come across groups of musicians in the streets practising and co-experimenting with the musical numbers they are scheduled to play.

Another factor making for change has been the export of music and musicians which has accompanied outmigration from the highlands. At first the flow was principally to the nearby mining towns and to coastal cities. But later many migrant musicians found their way to parts of the United States and Europe, where they are now found, together with their Ecuadorian and Bolivian counterparts, playing Andean music (though mostly of the pan-pipes and guitar type) in the streets and plazas of many towns and cities. In the end, though, this traffic in musical cultures has been two-way and greatly facilitated by the development of radio, television and recorded music. Thus the musical life of the Peruvian highlands has similarly undergone an inter-breeding with newly introduced, more global genres.

El wayllarsh - originally a ritual dance-music associated directly with agricultural tasks and seasons became dramatised and re-interpreted in terms of carnival activities, and has eventually achieved a more general popularity across the region and is performed throughout the cycle of Saint's days fiestas and secular festivities. This process was marked also by the adoption of the Hispanic version of the name, namely buaylas. Furthermore, huaylas (and to a lesser extent the muliza, a type of song based on huaylas types of melody and phrasing) has become one of the more 
popular kinds of music and dance among the working and lower-middle class populations of Lima and other cities of Peru. It is now the commercially-produced recordings of urban huayno (which is a highland's style of music similar to huaylas) that dominate the market for popular disc music. This type of huayno differs, however, from original highland versions by the combining of a singer (usually a woman, such as Flor Pucarina from the Mantaro area) and a 'typical' orchestra made up of saxophones, clarinets, harp and violins. According to Romero (1997:17), the reason for this innovation is simple, namely that with electronic amplifiers one can mix the two elements without the singer's voice being drown by the orchestra. In addition, the singing style tends to be more 'suavesita' (soft and sweet).

Over the last two decades or so a newer huaylas type of music has emerged called 'chicha', which is a mixture of the Andean huayno and cumbia from Colombia. It is played on electronic guitars and keyboards and Caribbean bongo drums. Chicha music has quickly become extremely popular, especially among the younger age groups, and is now the more usual type of music played by disc jockeys at social dances (bailes sociales) throughout the Mantaro. These dances often take place in local community halls where the young and single can easily meet and interact with members of the opposite sex. An entrance fee is charged but young people point out that enjoying chicha dancing and music entails no obligation such as one finds when participating in fiesta events organised by named sponsors (padrinos). Furthermore, dances can take place all-year round, and are also included in the programmes of village and town fiestas. 
A further development has been the formation of dance groups or associations that specialise in the reinvention and performance of particular dance dramas and routines. These dance groups, it appears, proliferated during the 1980 s and early 1990 s when it was difficult to move around because of the risks of violence posed by the presence of the Shining Path (Sendero Luminoso) movement and the Army who competed for political and territorial control. This situation encouraged the pursuit of more localised forms of entertainment, of which formation dancing seems to have been one. Over the years, these dance groups have evolved into more formal associations that regularly perform at local and regional festivals. They also practice hard to improve and embellish their specific Andean dance and musical routines. Since many of the members of these dance associations are unmarried youngsters who openly show their enthusiasm for such activities, this underlines the main conclusion of this short overview of changes in musical styles and activities: namely, that there is little evidence that, in the face of 'modernity', social groups in the Mantaro region have ever distanced themselves significantly from Andean cultural practices, nor have they switched wholeheartedly into new globalised genre. Moreover, the dissemination of chicha-style music does not herald the demise of Andean dance and musical traditions.

\section{A musical renaissance of the early twentieth century: rediscovering the English countryside}

Let me now turn to my second musical scenario 
which raises more the issue of musical composition. This concerns, what has been described as, the English Musical Renaissance of the early part of the twentieth century, when the myths and imagined realities of rural England were 'rediscovered'. Prior to this, the Victorians had a thriving, popular musical culture with music halls for working people and 'piano in the parlour' or domestic music-making (which created a huge market for music publishing) for the middle classes (Stradling and Hughes 1993: 12). Only the upper classes could afford to attend public concerts of the Philharmonic Society and the Italian Opera in London. There was also a good deal of choral music sung by church choirs and local choral societies throughout the country but little effort made to go beyond the standard repertoire of J.S. Bach, Handel and Mendelssohn. And the gentry showed little interest in music-making, preferring instead to devote its time to hunting, shooting and empirebuilding. In addition, while government lavishly funded the British Museum and the National Gallery, musical ventures received very low priority.

The stirrings of something new had begun in about 1890 when this idea of a musical renaissance took roots in the music academies of London, with its headquarters at the Royal College of Music. The movement soon became closely linked to the efforts of Cecil Sharp and his friends to initiate a large programme aimed at recording as many as possible extant English folk songs and melodies before they died out altogether. These efforts were directed principally towards the countryside of southern England. ${ }^{17}$ 
A point of interest is that it was not a composer but rather a poet with little or no interest in music, A.E. Housman, who first sparked off this renewed interest in the countryside scene. In the mid 1890 s he wrote a famous a poem cycle entitled $A$ Shropshire Lad, based on his experiences of the people and places of the Anglo-Welsh marshlands. His poem appealed to the late Victorians and by the turn of the century it was "being hailed as a modern version of Wordsworth's Lyrical Ballads and holding a similar significance for English culture. Young poets made a beeline for the borderlands..[and] [w] hen 1914 arrived, the English officer class packed a volume of Housman into its kitbag and took the Shropshire lad into the trenches" (Stradling 1998: 179). One such officer was the composer George Butterworth, who was famous for his settings of Housman's poems and who died at the Battle of the Somme. Later Ralph Vaughan Williams, who became the doyen of the revival movement, declared that setting Housman to music became a passport for the 'Kings Highway', "the officially prescribed route for national music" (Stradling 1998: 181). 18

Ralph Vaughan-Williams: The musical visionary of the English countryside

I want now to focus on the contribution of Vaughan Williams. $\mathrm{He}$, together with his close friend Gustav Holst, studied at the Royal College of Music where they became involved in building a new "historicalpastoral' music geared to rediscovering the gems of the Tudor period of Purcell and establishing a bridge with the English folksong tradition. 
Vaughan Williams was both a promising composer and an accomplished academic. He first made his mark through music scholarship rather than composing. Then, quite out of the blue he was approached by an Anglican clergyman to edit a new version of The English Hymnal. This offer was all the more surprising since Vaughan Williams declared himself to be agnostic. But the clergyman had come with the strong recommendation of Cecil Sharp and really wanted Vaughan Williams to do the job, which he quickly agreed to take on. In the end it took two years (instead of the two months originally proposed) to complete the task, but Vaughan Williams enjoyed every minute of it. In the process he re-harvested a great deal of good early English music, including the famous piece which he used to compose one of his earliest and best received works, the Fantasia on a Theme by Thomas Tallis. He also used the Hymnal to publish some of his own original hymns as well as some written by his friends Gustav Holst and John Ireland. This editing work bolstered Vaughan Williams' enthusiasm for the oral collection of folk melodies and songs which, from about 1904 onwards (following the inspiration of Cecil Sharp), he devoted much time to.

Over his lifetime, Vaughan Williams' compositional output was immense, covering many songs and song cycles, choral and chamber works, concertos for violin, oboe, cello, piano, tuba, and harmonica, and many orchestral works comprising nine symphonies. He lived a long life and became the leading composer of the new English school and a well-known academic musician. He evolved an influential network of social ties with fellow musicians, friends and others in the arts and sciences, and undoubtedly this affected his 
production of music and ideas.

He grew up in a privileged social environment in Gloucester, close to the Welsh border. His paternal line boasted several generations of distinguished lawyers and his mother was a descendant of Josiah Wedgewood the founder of the pottery empire and the niece of Charles Darwin. The men of these families had been educated at Oxford and Cambridge and over several generations many of them became notables in science and the arts. Vaughan Williams received a typical Victorian public (i.e. upper class private) school education with the bonus that Charter House where he studied possessed a strong musical tradition.

At Cambridge University, where he obtained a D.Mus., he became good friends with two musically talented brothers, the sons of a country vicar from Yorkshire. Vaughan Williams was a frequent guest at the village rectory and his most famous song Linden Lea ${ }^{19}$ received its first public performance there in 1902. He met his wife in Cambridge - a gifted violinist, good enough to play before Tchaikovsky on his visit to the university in the $1890 \mathrm{~s}$. Another friend at Cambridge became a famous organist, an instrument which Vaughan Williams also studied (Day 1998: 18).

After Cambridge, at the Royal College of Music in London, he made many friends but it was Gustav Holst who became a life-long buddie with whom he shared his ideas on music and all the drafts of his compositions as they evolved, as also did Holst with him. At the time Holst had to supplement his meagre 30 
pounds-a-year grant by playing the trombone in a seaside light orchestra on the Brighton pier. He hated it but it helped him to develop his knowledge of orchestral sounds and orchestration which became as important for Vaughan Williams as for himself. Soon after their acquaintance, they began their celebrated 'field days' together. That is, each week they would spend a day or two listening to and criticising each other's compositions-in-progress and swapping ideas. These meetings continued for some forty years, up to the death of Holst. As their letters indicate, their friendship was strong enough for them to be openly critical and frank about each other's compositions. One nice anecdote told by Vaughan Williams' second wife in her biography of him describes how on one occasion he was pressed for time to complete and orchestrate one of his symphonies. It seemed impossible to finish and get the parts to the orchestra in time for the rehearsal, so in desperation he asked Holst to come over and help him, which the latter did most willingly. This is one among many recorded instances of how they collaborated in the co-production of their individual pieces of music. Of the two, Holst was the more accomplished and talented orchestrator and interpreter, and Vaughan Williams perhaps the more inspired composer and blender of melody and mood.

Their partnership, which extended to many other music-related activities such as conducting, training choirs and orchestras, giving music classes, and contributing to scholarly work, lasted for about forty years, and many of these activities (especially their compositions) were to a considerable degree co-planned or co-produced. Reciprocally, this was their most 
important friendship and professional bond. When Holst died he left Vaughan Williams with his most cherished possession - a tuning fork that had once belonged to Beethoven which an admirer had given him (Heffer 2000: 82).

However, this relationship was not the only one of its kind for Vaughan Williams, since he was also helped considerably by two other musicians who transcribed and orchestrated his works ready for publication. Naturally they had quite a bit of discretion when it came to cutting or rewriting passages and they also experimented with alternative instrumentation and alternative endings to some compositions. One of them he had met when he was commissioned to write the film music for Scott of the Antarctic, which subsequently became his $7^{\text {th }}$ Symphony, Sinfonia Antarctica. Vaughan Williams also had close ties with Gerard Finzi and his group of friends; and much earlier in his life he spent many hours with George Butterworth who perished in the First World War. Furthermore, if one were to unpack Vaughan Williams' overall network of ties ${ }^{20}$ with contemporaries who shared an interest in roughly the same types of music and socio-political position as himself, then we would run across other similar cases. For example, Gerard Finzi (Vaughan Williams' protege) spent a good of time with Howard Ferguson. Both were sympathetic to the musical renaissance but of a younger generation. They shared their musical compositions with each other in practically the same way as did Vaughan Williams and Holst, and when Finzi died Ferguson took it upon himself (with assistance from Finzi's two sons) to complete a number of Finzi's unfi- 
nished orchestral works. Then, not many years after Finzi's death, Ferguson announced that he would not be composing anymore because he had said what he had to say! Therewith he devoted himself energetically to publishing academic books on music.

Another interesting facet of Vaughan Williams' mode of composition was that he was not only willing to learn a thing or two from Holst, but he extended this strategy to embrace the melodies and harmonic ideas from many other people's music. He was perhaps the most remarkable of musical magpies of the twentieth century. During his youth he collected and recorded over 800 English folk songs and melodies, which formed a database - alongside Vaughan Williams' favourite tunes and rhythms drawn from a variety of baroque and classical-romantic composers - for a life-time of composing. One book on Vaughan Williams' life and music devotes a whole chapter to what is called 'The simple kleptomaniac' (Day 1998, chapter 8). Vaughan Williams, it seems, had no qualms about 'stealing' bits and pieces from any musical source. So, in addition to English folk songs and sea shanties, he regularly helped himself to musical motifs and harmonic sequences from Beethoven, Thomas Tallis (the early English Tudor composer), and even from the music of his best friend Gustav Holst, drawing in particular from the latter's famous symphonic suite The Planets, as well as from a wide range of works by other contemporaries, including traces of Shostakovich and Prokofiev. However, despite Vaughan Williams' extensive 'pilfering', he nevertheless managed to blend together these various ingredients to produce music of great distinction and originality. 
None of his achievements would have been possible without the backing he received from a well-oiled network of highly-placed kin, affines, friends and musical colleagues who were, in one way or another, enrolled in the same broad social movement aimed at establishing a revitalised English style of music through the idiom of folk song. Like many other artists and intellectuals of the period, this movement was part of an attempt to further the democratisation of English society through the promotion of worker education, women's rights and socialist ideals. One of the composers, Ethel Smyth, served a prison sentence as a suffragette, and some of the group had strong ties with members of the Bloomsbury group associated with Virginia Wolf.

This sketch of Vaughan Williams' life and work brings us back to the earlier general point I made about musical creativity, namely that, for a large part, it is the product of the social relations in which people are embedded and engaged. All musical experience is a mixture of shared feelings, collective endeavours and individual talents, tastes and desires. Its production and dissemination is also affected by the availability of financial backing and the support of strategically-placed cultural brokers, of which Vaughan Williams had many since he came from the intellectual elite. In this respect, musical activities, and the arts more generally, make up an arena in which many actors attempt to negotiate their diverse interests, enrol others and further their own ambitions. This generates the potential for both co-operation and competition, and in this sense music is co-produced. As we have seen for Vaughan Williams, sometimes this allows for certain 
actors' networks to congeal into more solid 'schools of thought' which are able to launch musical programmes and project themselves as social movements geared to the production and promotion of specific musical and cultural genre.

Another dimension concerns the processes of composition itself. It must not be assumed that composing and scoring musical works is a linear or one-off process. In fact, the writing of a given symphony or song cycle acquires its own distinctive form or end-product only after many modifications have been made to the musical text during the course of it being composed, experimented with and further refined. This process is analogous to how scientists struggle to create their theories or explanations, and artists their paintings. The changes that emerge at successive stages in the process result not only from the individual's own inspirational, cognitive and technical understandings and capacities but also from the impact that the wider field of relationships, resources and cultural styles have on the making of the composition. In short, what we need is a sound understanding of how the social production and transformation of knowledge and meanings in musical practice take place.

\section{A word of thanks}

I owe a lot to many persons who have supported me in the course of my career and from whom I have learnt much. Also, like Vaughan Williams, my work at Wageningen has been co-produced through a series of ongoing relationships and shared experiences with colleagues, students, friends and family, and, perhaps 
even more significantly, by those many individuals who became good friends with my wife and I during the periods of fieldwork we undertook in Zambia, Peru and Mexico. That's the challenge and the beauty of my profession.

Let me now single out just a few who deserve special mention. First, I owe a great deal to those with whom I have published books, chapters in books and journal articles, and with whom I have spent many enjoyable hours struggling with the interpretation of research findings, namely Bryan Roberts, Alberto Arce, Jan Douwe van der Ploeg, Magdalena Villarreal and my wife Ann Long. Ann has not only often written and re-edited with me much of my published work, but she has also been the originator or catalyst of many of my better ideas. For all this and much else, I extend my heartfelt appreciation. Our two adult children, Alison and Andrew, and their spouses and the six grandchildren we now have, remain for Ann and I the most valuable, long-lasting and yet still-unfolding composition of all time.

From the time of my arrival in September 1981 until today, I have received the full support of this University. For this I am most grateful, and would especially like to thank the present Rector, Bert Speelman, and his predecessor Cees Karssen who brought me back from Bath. Thanks also go to Piet de Visser and his staff for all the assistance given to me and my Chair Group. In addition, I would like to acknowledge the support and guidance I have received from the staff of the now unfortunately dissolved Bureau Buitenland, whose former head, Chiel de 
Ranitz, continues to be a good friend.

I have been fortunate in having excellent colleagues in my Chair Group. In particular I would like to thank Jan den Ouden and Dirk van Dusseldorp for twenty years of good friendship and support. I am particularly grateful to Jan for joining forces with me in successfully steering the Chair Group through the many troubled waters of administrative restructuring which unfortunately has become a constant fact of life at Wageningen. I would also like to express my appreciation to Nannie Brink and Jos Michel for their secretarial and administrative backup and devotion. The research life of the group has always been lively, and is now enhanced by the establishment of the new Disaster Studies unit. Staff and postgraduates have regularly challenged my views and spurred me on to produce better analysis. They have also - each in their own way - played a role in mapping out new research terrain.

Others who deserve special mention and have contributed to an enjoyable academic life in Wageningen include Franz and Keebet von Benda-Beckmann, Niels Röling, Cees Leeuwis, Iteke Weeda, Louk Horst, Linden Vincent, and Paul Richards. Finally, I wish to thank Jens Andersson and Dick and Chris Kendrick for helping with the preparation of the power point presentation used in my lecture. 


\section{Bibliography}

Adorno T.W. (1976) Introduction to the Sociology of Music. (trans. E.B. Ashby) New York: Seabury Press

Arce, Alberto and Long, Norman. (eds) (2000). Anthropology, Development and Modernities: Exploring Discources, Counter-Tendencies and Violence. London and New York: Routledge.

Bakan, Michael. B. (1999) Music of Death and New Creation. Experiences in the World of Balinese Gamelan Beleganjur. Chicago and London: The University of Chicago Press.

Blum, David. (1986) The Art of Quartet Playing: The Guarneri Quartet in Conversation with David Blum. Ithaca, New York : Cornell University Press.

Bradby, Barbara. (1999) "'Vengenace is Sweet": A Herdswoman's Recompense in the Music of the Mantaro Valley'. Unpublished paper. Forthcoming 2002.

Budd, Malcolm. (1985) Music and the Emotions. London: Routledge and Kegan.

Day, James. (1998) Vaughan Williams. Oxford and New York: Oxford University Press.

DeNora, Tia. (1995) Beethoven and the Construction of Genius. Musical Politics in Vienna 1792-1803. Berkeley, Los Angeles and London: University of California Press. 
DeNora, Tia. (2000) Music in Everyday life. Cambridge: Cambridge University Press.

Gell, Alfred. (1998) Art and Agency: An Anthropological Theory. Oxford: Oxford University Press.

Golinski, J. (1998) Making Natural Knowledge: Constructivism and the History of Science. Cambridge: Cambridge University Press.

Heffer, Simon. (2000) Vaughan Williams. London: Weidenfield \& Nicolson.

Kivy, Peter. (1980) The Corded Shell: Reflections on Musical Expression. Princeton: Princeton University Press.

Kivy, Peter. (2001) New Essays on Musical Understanding. Oxford: Clarendon Press.

Laite, Julian and Long, Norman. (1987) 'Fiestas and Uneven Capitalist Development in Central Peru' in Bulletin of Latin American Research, 6, 1: 27-53.

Long, Norman. (2001) Development Sociology: Actor Perspectives. London and New York: Routledge.

Long, Norman and Long, Ann. (eds) (1992) Battlefields of Knowledge: The Interlocking of Theory and Practice in Social Research and Development. London and New York: Routledge. 
Mendoza, Zoila, S. (2000) Shaping Society through Dance. Mestizo Ritual Performance in the Peruvian Andes. Chicago and London: The University of Chicago Press.

Ridley, Aaron. (1995) Music, Value and the Passions. Ithaca and London: Cornell University Press.

Romero, Raul. (1997) 'Cambio Musical y Resistencia Cultural en los Andes Centrales del Peru', in Revista Cultural de la Sierra Central, Segunda Epoca, Nr. 5.

Stradling, Robert. (1998) 'England's Glory: Sensibilities of Place in English Music 19001950', in Leyshon, A., Matless, D. and Revill, G. (eds) The Place of Music. London: Guildford/Longman.

Stradling, Robert and Hughes, Meirion (1993) The English Musical Renaissance 1860-1940. Construction and Deconstruction. London and New York: Routledge.

Villarreal, Magdalena. (1994) Wielding and Yielding: Power, Subordination and Gender Identity in the Context of a Mexican Development Project. Ph.D. thesis, Wageningen University. 
I During my teenage years I was a junior exhibitioner at Trinity College of Music, London, after which I served in the Royal Air Force as a national service conscript. As a result $I$ was posted to Malaya (now Malaysia) for two years where I learnt little about music and more about air traffic control, colonial rule, ethnic strife, and the plight of peasant households and rubber plantation workers whose livelihoods were severely disrupted by war. One day one of our fighter aircraft returned from a mission with no brakes and we were forced to direct the landing towards the paddy fields that lay at the end of the runway. The aircraft careered off into the paddy, caught fire and the pilot luckily escaped. But the plane had run straight into a water buffalo, killing it instantly. That left me with a major problem, namely having to negotiate the terms of compensation with a bunch of irate peasant farmers. In the end they got the better of me and received well above the market price. Their principal argument was that this was a pedigree buffalo which would have bred many more of its kind. So the peasants won, and I lost. In hindsight this set the die for my future career in the sociology of rural development

${ }^{2}$ More generally, whenever brass bands strike up we are reminded of public occasions when national, regional or local sentiments run high. Brass bands became popular in the Victorian era in Britain, following the invention in the 1820 s of the piston valve and the manufacture of much improved chromatic instruments for treble, bass and intermediate pitches that were relatively easy for amateur musicians to learn to play. By the 1850 s, brass bands had quickly become a major leisure time pursuit among workers in the mines and factories of industrial Britain. Many bands were sponsored by employers or local municipalities or funded by public voluntary subscriptions. An interesting detail is that the War Office often donated uniforms, paid the bandmaster a stipend, and made 
available army drill halls for practice sessions - its probable motive being the rapid mobilisation of men (and even whole bands) for military service in the likelihood of hostilities in Europe or the colonies.

${ }^{3}$ An extreme example of this approach is that of Adorno's (1976) Introduction to the Sociology of Music which connects types of music to different cognitive habits, modes of consciousness and cultural epochs. Adorno is particularly interested in issues of modernity. He gives the example of Schoenberg (the twelve note serialist composer who broke with the harmonic and melodic orthodoxy of the early twentieth century) whose work, he argued, had the capacity to "foster critical consciousness because its materials were organised in ways that countered convention and habit. By avoiding musical cliché, and by preserving dissonance instead of offering musical resolution and gratification, progressive music had the power to challenge cognitive, perceptual and emorional habits associated with the rise of 'total sociation', habits that reinforced, as a matter of reflex, relations of power and administration in ways that made those relations seem natural, inevitable and real" (DeNora 2000: 1-2).

${ }^{4}$ For those interested in learning more about this theoretical position, see my more recent overviews, Long and Long (1992), Arce and Long (2000) and Long (2001).

5 This stress on individual creativity has, of course, encouraged especially within the fields of western science and the arts - a cult-like celebration of genius.

6 Peter Kivy's (2001) recent book on the idea of musical genius contests DeNora's account on the grounds that it is far too biased towards a social construcrionist view. According to him 
the "methods employed in Beethoven and the Construction of Genius have dissolved the mystery of genius" (Kivy 2001: 217). Of course the debate is immediately resolved once one clarifies that what DeNora is essentially concerned with is how reputations are made or lost, and how notions of genius or whatever are culturally constructed and strategically promoted.

7 For a recent critical review of different approaches to the study of knowledge construction and transformation, see Golinski (1998), also Long (2001:169-88).

8 Lifeworlds are 'lived-in' and often 'taken-for-granted' social worlds that are actor rather than observer defined. They should not be viewed as cultural or institutional 'backcloths' that frame how individuals act, but instead as the product of individuals' constant self-assembling and re-evaluating of relationships and experiences. Thus lifeworlds embrace actions, interactions, meanings and values and social practices that give shape to an array of specific personal, social and collectively-organised spaces.

9 For an excellent ethnographic analysis of such danzas performed by different types of dance associations in San Jeronimo, Cuzco, see Mendoza (2000). Similar fiesta dance troupes are also found in the Mantaro Valley where I have worked, and throughout other parts of the Peruvian Andes. While the dances, costumes and music differ somewhat, broadly similar conclusions can be reached in respect to their role in making visible and reworking ethnic identities, and giving meanings to a multitude of new experiences of 'modernity' and change. See Laite and Long (1987: $28 \& 51$ ) for some parallel observations about Mantaro fiestas which we argue "must be seen as organisational vehicles for reaffirming, reconstituting or 
reordering social relacionships and networks... These fiestas, then, are many things - recreational and political moments, instances of display and prestige, and structures of communication. As communicative devices they express not only cultural - urban and rural - structures of the region, but also the patterns of regional economic differentiation".

10 This issue of dealing with the 'feelings' side of music and whether or not specific types of music arouse certain emotional states in listeners have been hotly debated over the past two decades and has proved difficult to resolve. See Kivy (1980), Budd (1985), Ridley (1995) and Kivy (2001 Part II.'Music and the Emotions (Yet Again')').

11 Many forms of contemporary classical music are difficult to grasp (particularly at first hearing) because they cast aside the melodic and harmonic compass bearings of mainstream musical forms. One of the most provocative stances is that of John Cage who made his name with his 'prepared piano' ( i.e. piano in which an assortment of bits of wood, and flotsam and jetsam had been deposited), which he then experimented with to see what of kinds of unusual timbres would be produced. He also experimented with sounds based on chance procedures and indeterminacy. But his pièce de résistance was 'non-music' which consisted entirely of silence. He encitled this 'work' as 4 minutes and 33 seconds. I am at a loss to know how to interpret these products, which seem to be more about sound bites and challenging established conventions than about music as we usually conceive it

12 But, I hasten to add, music and dance were never the major focus of my reseatch.

13 An important aspect that I cannot explore in detail here con- 
cerns the relationship berween this Andean rrtual and the celebration of Saints of the Catholic church. In broad terms, the tagging (or herranza) ceremony does not appear to have a Christian element but it does take place at the time of the Christian calendar when the festivals of Santiago (Saint James), San Juan and San Octavo are celebrated at the beginning of the Andean winter solstice when the sun is farthest from the equator. The three saints represent poverty and attempts to rise above it, and in this sense they reflect some aspects of the tagging ceremony. The herranza celebration means an outlay on new clothing and victuals to please the mountain spirits and to ensure the continuing prosperity of the herd.

14 This account draws heavily on Barbara Bradby's (1999) vividly recorded and interpreted performance collected in 1983. She provides detailed analysis both of the text and melodies of the songs. The music is distinctive in that, unlike most other music of the Mantaro region, it is not built upon a pentatonic (i.e. a five-full-note) scale. Here I can only provide a brief sketch of the event. Bradby's own line of analysis fits well with the more general theoretical argument 1 wish to make in this lecture. See Romero (1997: 7-11) for an additional narrative that describes the full sequence of events for the tagging ritual: from the first offerings made to the spirits, followed by the preparation of a ritual table (mesa) on which are placed various items associated with the livestock (e.g. clay figures and stones representing individual animals, plants and flowers from the mountains, drinks including some alcohol, sugar or food items, and sometimes an image of Santiago (Saint James), as well as the tools used for the tagging), to the actual petformance itself and its aftermath of dancing, drinking and merriment. The ritual preparations begin on the eve of the tagging ceremony and go on late into the night of the central 
day of the ceremony. During the 1970s, my wife and I participated in similar rituals.

${ }^{15}$ This song was sung in Quechua. Bradby suggests that the term used here (i.e. tayta patronlla) is best translated as 'Father owner' since it is used to show respect to a senior person of authority.

16 See Romero (1997: 16) for a fuller discussion of these changes.

17 Cecil Sharp was a founder member of the English Folk Dance and Music Sociery which is still going strong with many hundreds of affiliated local clubs throughout the UK. Two of the most prominent composers cooperating with Sharp from the early days were Vaughan Williams and George Butterworth.

18 The landscape of the countryside was linked also to seascapes which were of central importance to the construction of an Englishness of the period since sea power was a source of trade and empire. Hence sea shanties, the Navy and merchant seamen, and commercial and political ventures abroad were closely associated.

${ }^{19}$ This is sometimes assumed to be a genuine 'folk' melody but was in fact Vaughan Williams' own original composition.

20 For example, composers, musicians, academics, editors at music publishing houses, organisers of folk dance and folk music activities, amateur musicians and singers who were often the first to try out his compositions, choir masters at the Cathedrals, and politicians and scientists in touch with the music scene. 